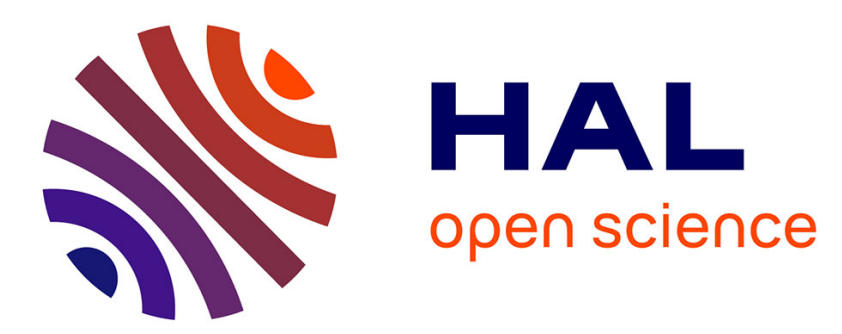

\title{
'Similar but different': Social representations of health according to gender for French youth
}

Marie-Anastasie Aim, Solveig Lelaurain, Nicolas Khatmi, David Fonte, Inna Bovina, Lionel Dany

\section{- To cite this version:}

Marie-Anastasie Aim, Solveig Lelaurain, Nicolas Khatmi, David Fonte, Inna Bovina, et al.. 'Similar but different': Social representations of health according to gender for French youth. Journal of Health Psychology, 2018, pp.135910531878189. 10.1177/1359105318781894 . hal-02527754

\section{HAL Id: hal-02527754 \\ https://hal-amu.archives-ouvertes.fr/hal-02527754}

Submitted on 1 Apr 2020

HAL is a multi-disciplinary open access archive for the deposit and dissemination of scientific research documents, whether they are published or not. The documents may come from teaching and research institutions in France or abroad, or from public or private research centers.
L'archive ouverte pluridisciplinaire HAL, est destinée au dépôt et à la diffusion de documents scientifiques de niveau recherche, publiés ou non, émanant des établissements d'enseignement et de recherche français ou étrangers, des laboratoires publics ou privés. 
Title:

"Similar but different": social representations of health according to gender for French youths

Marie-Anastasie Aim ${ }^{1}$, Solveig Lelaurain ${ }^{1}$, Nicolas Khatmi ${ }^{1,2}$, David Fonte ${ }^{1}$, Inna Bovina ${ }^{3}$ \& Lionel Dany ${ }^{1,4,5}$

${ }^{1}$ Aix Marseille Univ, LPS, Aix-en-Provence, France

${ }^{2}$ INSERM, Sesstim - UMR 912, Faculté de Médecine, Marseille, France

${ }^{3}$ Department of Clinical and Legal Psychology, Moscow State University of Psychology and Education, 127051, Moscow, Russia

${ }^{4}$ Aix Marseille Univ, CNRS, EFS, ADES, Marseille, France

${ }^{5}$ APHM, Timone, Service d'Oncologie Médicale, Marseille, France

Correspondence concerning this manuscript should be addressed to Marie-Anastasie Aim, Laboratoire de Psychologie Sociale, Aix-Marseille Université, 29 avenue Robert Schuman, 13621 Aix-en-Provence, France. Telephone: 0033683762417

Email marieana.aim@gmail.com 
Abstract: This study focuses on life experiences and representations related to gender in the context of health among young French lay people aged from 18 to 21 years $(N=47)$. Qualitative analysis of the discursive content of nine focus groups illuminated the lay thinking underlying gender issues in the health context. Broadly speaking, group composition (i.e. unisex, mixed) had an impact on participants' discourse construction. Through their discourses, participants came to "naturalise" the health issues and practices of each sex/gender through the biological specificities of men and women. In addition, discourse content underscore a differentiated "imperative of health".

Keywords: Health behavior, Gender, Identity, Focus groups, Social representations, Youth 


\section{Health and gender}

Among many factors that may affect people's health, such as culture, socioeconomic status, age, and psychosocial factors (e.g., Marmot, 2005; WHO, 2011), health surveys have highlighted several inequalities between men and women (e.g., lifetime, health status, use of healthcare system, risk taking) (Doyal, 2001; WHO, 2011). It has been shown that gender has an impact on health and plays a crucial role in its perception. However, beyond biological differences, "man" and "woman" are identities related to social roles and status. Thus, it is important to consider the effect of socially constructed gender on health beliefs and practices (e.g., Connell, 1995; Doyal, 2001). The World Health Organization and the United Nations have emphasized the importance of taking gender into account (Connell, 1995). Yet, authors have pointed out the tendency of these reports to focus solely on women's health when the relationship between gender and health must necessarily be considered for both men and women (Bates, Hankivsky, \& Springer, 2009). The social construction of women's and men's health and illness (Conrad \& Barker, 2010) has been highlighted, notably through bodily issues, throughout history, and across different cultures (e.g., Blaxter, 2016). Many studies have shown a conformity to "male roles" in risky behaviours whereas they have highlighted that women are more likely to express their pain and health issues as well as taking care of their own and others' health (e.g., Bernardes, Keogh, \& Lima, 2008; Connell, 1995; Courtenay, 2011; Ehreinreich \& English, 1973; Esplen, 2009;).

In public policies, “men's health" and "women's health" seem to be considered separately. However, it seems difficult to study one without taking the other into account. As underlined by Connell (1995), "public segregation policies" related to gender affect how "men's" and "women's" health is inscribed in the public sphere. For Fassin (2006), "the rhetorical opposition between French universalism and American differentialism" (p. 18) such as anti-communautarism and the division between public and private spheres in French 
Republican discourse can explain the difficulty (until recently) in thinking about "gendered" issues in France. Since the end of the 1990s, gendered and sexual issues have become political issues. In this changing context, both social and political, regarding the social status of men and women, it is useful to examine how individuals consider gender in the field of health, and more specifically the way in which women and men construct meanings concerning health for them, but also for the other sex/gender.

Taking gender into account is crucial in order to understand how lay people regard men and women's health (Doyal, 2001), and specifically in order to identify the lay thinking that guides them in their health practices. From this perspective, the social representation theory (Moscovici, 2008) offers a valuable approach for understanding gender issues and their implications for men and women's health.

\section{Social Representations, Health, and Gender}

As a content and process, social representations (SRs) constitute a particular modality of knowledge, generally referred to as lay thinking. As pointed out by Flick (1996), "the theory of social representations offers a model of social knowledge, its social construction, transformation and distribution, and describes the function of experience and knowledge in social practices” (p. 70). Moscovici (1973) defined SRs as a

system(s) of values, ideas and practices with a twofold function; firstly, to establish an order which will enable individuals to orient themselves in their material and social world and to master it, and secondly, to enable communication among the members of a community by providing them with codes for social exchange and a code for naming and classifying unambiguously the various aspects of their world and their individual and group history. (p. xiii). 
The theory of SRs adopts a notion of knowledge and representation as collective (or social) phenomena, the social construction of reality and meaning, and the process whereby external realities enter internal worldviews (Flick, 1996). Moreover, people build SRs not by the single, internal analysis of semantic contents of a representation, they elaborate meanings by referring to others meanings governing the symbolic relationship between social actors. "The significance of SRs is always interlocked or anchored to more general significance, which take place in the symbolic relationship of a given social field" (Doise, 1992, p. 189). From this perspective, individuals are considered as social and cultural beings. Consequently, through their SRs of health and illness, people talk about their relationships with others, the world, and the social order (Apostolidis \& Dany, 2012; Herzlich, 1973).

Moreover, through the conflictual relationship between health and illness and between individuals and society, SRs of health and illness connect the biological to the social level (Herzlich, 1973). As the physical embodiment is specific to each gender, we might consider that the connection between biology and social life could underlie particular health representational discourses while taking the gender into account. We should consider that SRs both shape and maintain social identity (Jodelet, 1991) because social identity should be considered as a social location within representations (Duveen, 2001). Moloney (2010) underlines the fact that "imposed identity is typically manifested through immutable characteristics such as ethnicity, age, or gender and is argued to be a powerful force in a social positioning" (p. 158). Considering individuals as "socially located", SR theory seems particularly relevant for studying lay thinking related to gender in a health context because health constitutes a prototypical research field for studying identity and gender issues according to a cultural object (health) that emphasizes values and ideologies according to selfmanagement, behavioural control and gender norms in the cultures of Western societies (Bell, 2017; Lupton, 1995). 


\section{The Present Study}

Some research has investigated the lay health worldview (e.g., Flick, 2001; Hughner \& Kleine, 2004; Jovchelovitch \& Gervais, 2001; Murray, Pullman, \& Rodgers, 2004). Notwithstanding the relevance of studying representations and determinants of health, most of the published work has focused on illness (cf. Lawton, 2003). Some studies, mainly in English-speaking countries, have highlighted the impact of gender on health representations and practices (e.g., Courtenay, 2011; Ehrenreich \& English, 1973) and few studies have explored lay thinking about gender in the health context (e.g., Emslie \& Hunt, 2008; Pietilä \& Rytkönen, 2008). To our knowledge, no study has focused on lay thinking about gender related to health in its broadest meaning. Thus, the purpose of this research is to explore and understand SRs related to gender in the health context in young French people. As health mediates individual, relational, identity, group and societal issues at the same time, it appeared interesting to focus on a context of interactive exchanges and of co-construction and confrontation of ideas.

\section{Method}

Forty-seven participants (21 men and 26 women) were recruited via a university website. Participants were aged between 18 and 21 years $(M=18.68 ; S D=0.91)$. Six participants mentioned chronic illness issues (e.g., asthma, deafness), and 3 talked about health issues in their family environment (e.g., cholesterol, drug use). None of the participants lived with a partner or were parents at the time of this study.

Focus Groups (FGs) were selected as a "researcher-provoked" data collection method in order to gather data on a topic silenced in the public domain (Hine, 2011). This method enables social interaction to take place between participants and discourse to be co- 
constructed (Krueger \& Casey, 2009). FGs are envisaged as communication situations enabling the social dynamics allowing the development and the dissemination of SRs to be observed and analysed (Caillaud \& Kalampalikis, 2013). These discussions are shaped by multiple social contexts (such as participants' gender) that may affect the data (Hollander, 2004). Thus, in relation to the aim of our study we established different production contexts: a women's group, a men's group, and a mixed-gender group (cf. Appendix 1). An information note and a consent form were given to participants before the beginning of the FGs. Ethical approval for this research was obtained from the University Ethics Committee of AixMarseille University, France (n 2016-05-12-007).

Nine FGs were held between November 2015 and March 2016. They lasted 82.89 minutes $(S D=16.03)$ on average. FGs were led by two facilitators. The main facilitator was a woman, psychologist and PhD candidate, who took part in all FGs. The role of "back-up" facilitator was fulfilled by a man. Three researchers took turns in that task. One was a professor of social psychology, and the two others were psychologists and $\mathrm{PhD}$ candidates. Facilitators made sure to encourage interaction between participants (e.g., "Do you have examples to illustrate that?", “What do you think of what she/he has just said?") (Kitzinger, 1994). This study was conducted as one component of a larger research aiming to study (a) lay thinking of health (i.e. i.e. individual free associations of health-related terms followed by a collective discussion among participants), (b) representations and life experiences related to gender in health context (i.e. "Do you think that being a men/woman influences the way you represent your health?), and (c) parent to child transmission of health representations and practices (i.e. "Do you remember how your parents (your mother, your father) made you aware of health - how important it was to them - how the tool care of your health?"). In the context of this manuscript, the analysis of the speeches focused on gender-related reflections. 
From audio and video recordings, FGs were fully transcribed and completed with annotations concerning non-verbal communication and the dynamics of exchanges (Duggleby, 2005). In order to highlight the link between gender and discourse in mixed groups, the participant's gender was added in parentheses for each verbatim. Thematic content analysis and group dynamic analysis (Duggleby, 2005, Flick, 2014), conducted in French, were used in order to analyse the FGs content. A researcher triangulation (Denzin, 1978) was carried out with male and female researchers in order to take into account the potential impact of the researcher's gender on the analysis.

\section{Results}

The analysis of FGs content allowed us to access discursive logics marked by biological and social characteristics. This lay thinking is notably expressed with regard to similarities and specificities of both sexes/genders, the naturalisation of some health practices, the female body, and health norms and imperatives.

\section{Similar but different}

Spontaneously, the majority of participants pointed out an absence of differences between women's and men's health practices. However, in elaborating the discourse further, participants tempered their statements by underlining certain gendered (or sexualized) specificities related to biological and social beliefs and knowledge.

P1: Personally, that... Depending on gender, that can change the way you view health or not. [...] If that is the case, it's more to do with trends. Out of a concern to belong to certain social groups. If not, not. So, every individual, in any case, yes men and women's brains don't work in the same way. (Men1) 
Nevertheless, the gender gender composition groups had an influence on the spontaneous mention of this absence of difference between men and women. The majority of unisex groups (4 out of the 6 groups) refuted or tempered gender specificities of health at first glance. Only one group of men spontaneously mentioned the possibility of gender specificity and then participants were immediately concerned by the potential sexist aspect of this positioning. All of the mixed groups instantly underlined gendered needs and issues. P1(Wom.): Yes we have the same needs. Right away... being women we're going to think about certain things, they as men will think about other things. I don't have any examples right away, but...(Mix1)

Participants spontaneously referred to situations in former times or comparisons with "less developed" societies and cultures when they talked about men's and women's health. This "differentiated regard" is centred on discourses made of temporal ("before", "at the time" versus "now", "nowadays") and societal/ethnic ("in certain ethnic groups", "in backward societies" versus "in French society") oppositions. These discourses focus more specifically on women's status, natality, and a greater consideration of women's health. In contemporary Western society, women's sole function would not be to reproduce and they would have greater flexibility in taking care of their own health. Nevertheless, the oppositions stated do not guarantee total "equality" for "Western" women.

P1: It's new! Well, it's new... I think that in previous generations men and women had completely different ideas about good health and health [...] before women didn't have as many rights as they have today and uh... Their priority was well...that their children were in good health at home and that everything went well at school, that she was a good mother and a good housewife and was in good health. Whereas today, women have to, they have to do sport like men [...] they have to be in good health to take care 
of their children, all that, but now her own well-being is almost as essential as the rest. (Wom3)

\section{Naturalisation of health practices}

Interactions and the development of collective and individual thoughts during FGs led participants to mention the biological specificities of men and women (e.g., cognitive functioning, periods, maternity). The reliance upon "biological" explanations involved "gendered" diseases and a certain focus on gestation and procreation. By referring to the biological, participants “naturalised” men and women's differences regarding health. P2(M): Well, yes, there are certain diseases which affect men more than women and vice versa. $[\ldots]$ cervical screening, I haven't done that $[. .$.$] yeah of course we don't$ have the same worries. Even though there are certain diseases which affect both, uh... For example, breast cancer, uh, I'd be less inclined to... [...] I'd be less likely to be screened for that than for other things. I think, well it's... And then socially when you say “yeah I'm going to be screened for breast cancer people will say "Oh really? OK, are you hiding something from me?". (Mix1)

The analysis also indicates that women will be more inclined to comprehend and accept mental healthcare than men, whereas men will be more physically "resistant". Men would be confrontational or seek risk taking for fun or challenge. Women, for their part, would have a "natural" (instinctive, reasoning, need, sense) preventive stance because they could be the potential victim of external "aggression". By psychologising behaviours, discourses highlighted attitudes that were "natural in nature". This observation can underlie the naturalisation of certain practices considered as "innate", such as a better understanding of health and more effective health management for women. 
P1: A boy will be more inclined to act big [...] drink ten shots or something [...] a bit like... Like a Neanderthal you might say. Sort of "I want to prove that I'm better, that I'm this, that I'm that'. While ...With girls there isn't this need to prove themselves. $[\ldots]$

P4: Well, perhaps in order not to do just anything. Because they [girls] know that if they are completely plastered... They'll do just anything. So, yeah, you're right.

P2: No but I swear, seriously they have an instinct that men don't have. We are always testing our limits, always our limits without really knowing them. And women always have something which tells them "I must be careful".

P4: A little more sensible, yeah. They have to protect themselves. (Men1)

P3: They'll know better how to manage it than a man. While a man will panic straightaway not knowing what to do, a woman will be able to calm down and...

Manage it. [...] I think she will know how to manage both. Her stress in the beginning when she doesn't know whether she has it, if she has it or not. And if she has it she will know how to manage the disease better than a man. [...] They hide as well, I find that they hide behind their disease while women will move forward more, looking how to take care of herself. While a man will tend to hide more behind his disease... (Wom2)

\section{Aesthetics and the reproductive female body}

Participants expressed important differences in the health and social construction of men's and women's bodies. The societal requirement to have a healthy body is a bigger issue for women. Although normative pressures of the social definition of beauty also concern men's bodies, the size of the investment in the feminine aesthetic was described as more important. For participants, the imperative of concern for personal appearance is greater for 
women (e.g., social comparison, the search for the ideal body) as body dissatisfaction could lead to greater consciousness of the self, body, and health.

P4(Wom.): A woman is often more concerned about her weight than a man as well. They don't have the same relationship with food either, from a health point of view. $[\ldots]$

P3(Wom.): They are encouraged to pay more attention! With regard to their image which, again, society...

P1(Man): Perhaps they show their anxiety about their body more than men do $[\ldots]$ P6(Wom.): There's an image of women that they have to be slim, have a beautiful body, all that. (Mix3)

Biological characteristics regarding reproduction are a major element in the differentiation between the health practices of men and women. As discussed in FGs, these characteristics (periods, pregnancy, maternity) anchor feminine health in the mother's health category (potential and/or actual). Discourses expressed the crossover from woman's health to the (future) mother's health. Women's health practices seem to underlie a gender role imperative (maternity, care). This theme was discussed in all the FGs.

P5: It's a bit of an established thing that women take care of their children. Men, well they work or I don't know what. And so, the mother has more need to know about illness, how to look after them, what you have to do for such and such a disease, when a child is ill, or something like that. [...]

P1: Yeah, in any case she carries the child for nine months, so it's generally women who are the most concerned, rightly because it's about the child's health [...] We're thinking about the child's health. [...]

P6: That's the main difference; because she carries a child and we don't. (Men3) 
When a woman takes care of her own health, it de facto helps to take care of her family. However, when the health of the woman/mother is compromised by a disease, her health status/state does not absolve her from her family commitments. Woman's health is connected to family life whereas men's health is thought to be more "personal". What is thought to make a woman "stronger" and "resilient" is her capacity to take up the "challenges" which her gender identity presents her with.

P4: They are stronger. Women to take care of the home even when they are ill. You could say that it is a major stereotype but, they carry on as normal and look after their children, all that, while men they have the slightest thing, and behind it all it's like perhaps because we have things that men don't, we're stronger and because we don't only look after ourselves we take care of lots of things, so when it comes to health, we're stronger. In a manner of speaking. [...]

P1: In my opinion, I agree that it's more for the children. The mother has to be in good health in fact, seeing that she's looking after everything. The same for pregnancy, she has to be in good health. While the man only has to be in good health for himself. I think. (Wom1)

\section{Health norms and identities}

The results highlighted a social categorisation through which gender stereotypes related to representations of health practices are expressed. Participants described men as "autonomous", "strong", "robust", and "tough". These characteristics might lead the "strong" man to not pay/pay less attention to their own health ("I'm a man, I'm alright") which could lead to non-use of preventive care. Representations of women's health presented them as 
more "fragile", having a certain ease in expressing their feelings, and less likely to hesitate to seek help when needed.

P2: I think that men are... Not less affected but... Help me, who are...

P6: Who get used to it more easily? More quickly? [...]

P3: We're trained, in fact, from birth and all that [...] I don't know, we're perhaps trained to think like that, to try and resist, compared to... Well, not compared to women, but... [...] Well I don't know. Perhaps we're trained to think like that and are too much subjected to “you must be strong, you mustn't be ill, or being ill is nothing, you'll get back on your feet again" and all that.

P1: I know that when I'm ill I tend to say "well, it'll sort itself out" [...] I have a tendency, a little, to...

P4: Minimise things. (Men3)

Discourses (of both men and women) on men's practices in the field of health maintenance and disease management underlined their refusal to admit or recognise their (physical, moral, social) pain. This denial could be related to the maintenance of a certain virility (i.e. don't appear weak). Derogation from gender norms (i.e. "tough" man, "sensitive" woman) might lead to a reclassification of individuals through identification with the other sex/gender (being "called a woman" when one is a man, "behaving like a bloke" when one is a woman"). Representations of health and relationship with health practices thus activated a gendered logic (modalities of action, lived experiences, limits) that reinforce social categorisation between men and women.

P2: But yeah, it's the idea that women can be a bit more sensitive to illness, while men try to cope themselves. [...] 
P6: But, then, I know many women who...well, they are stronger than some women, than some men, or... It's true that there is a majority of women, but... There it's about being macho. [...] It's an expression, an expression which means that a woman who fights it is like a man, it's the expression of being a man. [...]

P2: Me, I can be a man and act really ditsy when I'm annoyed... Well no, ditsy... [...] Like a super irritating bloke when I've got a cold.

P3: If you don't, you tend to get treated like a woman, see?

P2: Yeah, and that's the word every time, it's a man when you're strong and a woman when you're weak $[\ldots]$

P3: Well you have to take responsibility. (Men3)

\section{Imperative of health and self-monitoring}

Generally speaking, health is considered as the outcome of work on oneself. This imperative of health is promoted through biology to build a relationship with the self and selfconcern. This seems all the more significant as it concerns the gynaecological/reproductive sphere. Through a form of "duty" or "normality", discourses highlight a feminine health identity characterised by a self-monitoring requirement. Female participants called their own ideal of women's health into question but even so, normative pressures result in their implementation of self-objectification and self-monitoring practices.

P5: I also think that everyone has to go there [to the gynaecologist] you have to take care of yourself a bit don't you? Because me, I don't feel really obliged to go there [...] I go there because it's for my well-being.

P3. Yeah well yes if you have to do it. [...] But as you said we are influenced by... [...] The idea of freedom is a little [vague movements with the hands] modern.

P5: I agree with her on that point all the same $[\ldots]$ 
P3: Because of what you see on the telly, like... Getting pregnant at sixteen, you don't want to get pregnant at sixteen, we're told "be careful", we're told all through middle school "use protection", so we're influenced. So, we're not completely free. We aren't told you have to go or you'll die tomorrow. But well... In case you go there. (Wom1)

Conversely, participants highlight a "mysterious" and a lesser investment (by men, health professionals, and health policies) regarding men's genital surveillance. More generally, discussions show lower levels of health information for men. Thus, health risks related to men seem to be considered as less "problematic" or "worthy".

P2: Yeah, we get less information, that's it.

P6: The basics which only affect men or women. In fact, even for us, there is no advertising on telly about testicular cancer. [...]

P6: With regard to sexuality I think that they in any case... Not more informed but it's directly with a professional, so if they ever have any questions they can get a clear answer. (Men3)

The Appendix 2 provides a summary of the results obtained regarding social representations related to gender in the health context.

\section{Discussion}

The goal of our research was to study SRs of health related to gender in a methodological framework promoting the reflexive nature and co-construction of ideas. By using a socio-constructivist approach to examine links between gender and health, our work aimed to understand individual, relational, identity, intergroup and normative issues at stake in health issues. 
The results showed that through health discourses, participants (re)constructed the symbolic and social status of men and women. The data highlighted the fact, more specifically for unisex groups, that gender differences regarding health are initially refuted or distanced. This result can be explained by the existence of a certain gap between social values ("men and women are equals") and life experiences of participants (health practices/issues are not similar for men and women) (Lahire, 2001). Regarding mixed groups, the attendance of members of the outgroup tends to promote the highlighting of spontaneous differences regarding gender differences in the health context.

Data analysis of FGs content also enables us to demonstrate a "naturalisation" logic of health and health practices of men and women ("gendered" diseases, focus on pregnancy and procreation) via the use of biological order (physical and physiological functioning). We can observe circular discursive logics that articulate biological and social spheres on an ongoing basis (Herzlich, 1973). By circular discursive logics, we wish to show that the evocation of the biological quasi-systematically leads to a reference to the social and vice versa. The circularity demonstrates a quasi-ontological entanglement, an interdependence of these two spheres. In other words, this circularity appears as "obvious" (see Lahire, 2001) to participants. It doesn't need to be explicit because it proceeds as a "natural logic" on the argumentative level (logico-discursive process that generates schematic argumentation, see Grize, 2015). These discursive logics also lead to the psychologising of men and women's health practices. Health representations transcribe broad visions of the world (gender relations) at biological level. Health becomes a signifier, signifying the relationship between individuals and the social order (Herzlich, 1973); the social order of which gender relationships are one of the foundations. Those circular discursive logics are expressed through bodies and their expression, and more specifically through body governance norms. The imperative of a healthy body is a more female-oriented duty than a male duty. The 
woman's "healthy" body is depicted by participants in close contact with the ideal female body (thinness). The link between aesthetic body issues and health issues lead women to devote greater attention to their body through self-objectification and self-monitoring practices (Fredrickson \& Roberts, 1997). Knowledge and representations related to the biological specificities of men and women anchor representations of women's health in reproductive issues, which is the main distinction between men and women's health practices. In one respect, the health of the (future) mother seems to impose on woman's health because discourses hint at a transitive relationship between the (future) mother's health and her children's health. The responsibility to oneself becomes all the more binding as it involves for women the consideration of their reproductive capacity and responsibility. When "female strength" is mentioned, it refers to the capacity of women to maintain their own health as well as their children's health.

FGs discursive content also highlighted an effect of gender stereotypes on health practices and issues (cf. Courtenay, 2011; Ehrenreich \& English, 1973). Lay thinking about gender in the health context presents women as fragile, taking care of their body and their health, and vouching for the health of others (Ehrenreich \& English, 1973). On the other hand, the man takes risks, is autonomous and tough, and doesn't feel the need to (or wouldn't dare to) seek help regarding his health (Courtenay, 2011). Men's difficulty in outlining their health issues can be linked to beliefs about masculinity (virility, control). These beliefs and practices are reinforced by an identity threat (being defined by other gender characteristics) that condemn individuals who derogate from gender norms. For women, these gender norms can be expressed by "self-concern/care" through a health-related "duty". Notwithstanding women's reflective ability, the normalisation of health practices (notably concerning the gynaecological sphere) seems to contribute to the substantiation (or even to the legitimation) of the social and medical governance of women's bodies (Ehrenreich \& English, 1973). For 
their part, men mentioned a type of male "disinvestment" in health (policies). As such, health risks related to men seem to be considered as non-problematic even though a wide range of risks is closely related to the male gender (Courtenay, 2011). According to Joffe (2007), characteristics of socially dominated groups allow us to define what socially dominant groups are not (e.g., women have periods, can carry a child, and men don't). In this regard, the women's body and health objectification process seems to constitute a necessary element for examining the risks, practices and imperatives of health for both women and men.

"Natural" differentiation logics as stated by participants show that health represents a cultural object through which SRs and practices are in close alignment with each gender's social status and position (Connell, 1995; Détrez, 2002). Representations of health express relationships with others, the world, and the social and structural order (Herzlich, 1973). Health, which is a fundamental value of Western societies (Bell, 2017), serves as a powerful instrument of the social regulation of gendered bodies. Generally speaking, representations produced by participants show that the structuring and legitimising framework of the biological constitutes a fundamental basis for explaining and justifying the imperative of health (Lupton, 1995) such as health institutions and policies (Foucault, 1979). Through their interactions, participants questioned this health and social/societal framework without jeopardising it. By invoking "biological health”, biopolitics (Foucault, 1979) can thus function in a framework that naturalises the social. Within the context of an imposed identity, such as gender, representations precede identity (Duveen, 2001). In that respect, the results seem relevant for questioning the health and prevention field. Indeed, health is portrayed as the result of work on oneself (Bell, 2017) that seems more congruent with the social role imposed on women (self-care, and take care of others) than with masculine "virility" (toughness, risk taking). 
Biological and social bodies are simultaneously subjects and agents of (health) practices. For their part, social health practices nurture frameworks in which bodies are assimilated and defined (i.e. bio-reflexive practices model, Connell, 1995). The social and the biological are closely related in the field of health. It seems necessary to us to take into account the circularity of certain discursive logics to facilitate the transmission of information in the health prevention and education field. Those goals require us to work on the influence of representational systems and their impact on biological beliefs and socio-cultural components on health and health practices.

The results described in this work reflect the most frequently reported themes, and therefore not all subjects mentioned by participants, or minority opinions, are reflected. Also, we have not taken into account the potential impact of "back-up" facilitators on discursive development. All participants of this study were students, and it could be interesting to study the health representations and practices related to gender of other people. Notably, it could be relevant to add an intersectional perspective (Doyal, 2001) to this kind of work. Moreover, and although group composition was included to the results analysis, future research could allow us to study in greater depth the impact of internal group dynamics (e.g., leaders, linking of male/female speech in mixed groups) on discursive content.

\section{Conflict of Interest}

The authors declare that they have no conflicts of interest concerning this article.

\section{Acknowledgments}

Support for this research was provided by the Mustela Foundation (France) and by the Foundation Maison des Sciences de l'Homme (France) and the Scientific Foundation of Russia 
for the Human Sciences. We would also like to thank interviewees who participated in the FGs discussion. Data were collected in the SocialLab of H2C2 platform at Aix-Marseille University.

\section{References}

Apostolidis T and Dany L (2012) Pensée sociale et risques dans le domaine de la santé : le regard des représentations sociales [Social thought and risks in the health field: The social representation perspective]. Psychologie Française 57(2): 67-81.

Bates LM, Hankivsky O and Spinger KW (2009) Gender and Health inequities: A comment on the Final Report of the WHO Commission on the Social Determinants of Health. Social Science \& Medicine 69(7): 1002-1004.

Bell K (2017) Health and Other Unassailable Values: Reconfigurations of Health Evidence and Ethics. New-York: Routledge.

Bernardes SF, Keogh E and Lima ML (2008) Bridging the hat between pain and gender research: A selective literature review. European Journal of Pain, 12(4): 427-440.

Blaxter M (2016) Health. Cambridge: Polity Press.

Caillaud S and Kalampalikis N (2013) Focus groups and ecological practices: A psychosocial approach. Qualitative Research in Psychology 10(4): 382-401.

Connell R (1995) Masculinities. Cambridge: Polity Press.

Conrad P and Barker KK (2010) The Social Construction of Illness: Key Insights and Policy Implications. Journal of Health and Social Behavior 51(S): S67-S79.

Courtenay WH (2011) Dying to be men: Psychosocial, environmental, and biobehavioral directions in promoting the health of men and boys. New-York: Routledge.

Denzin N (1978) The research act. Chicago: Aldine.

Détrez C (2002) La construction sociale des corps [The social constructions of bodies]. Paris: Seuil. 
Doise W (1992) L'ancrage dans les études sur les représentations sociales [Anchoring in studies on social representations]. Bulletin de psychologie 45(405): 189-195.

Doyal L (2001) Sex, gender, and health: The need for a new approach. BMJ Clinical Research 323(7320): 1061-1063.

Duggleby W (2005) What about focus group interaction data? Qualitative Health Research 15(6): 832-840.

Duveen G (2001) Representations, Identities, Resistance. In: Deaux K and Philogène G (eds) Representations of the Social: Bridging Theoretical Traditions. Oxford: Blackwell Publishers, pp. 257-270.

Ehrenreich B and English D (1973) Complaints and disorders: The sexual politics of sickness. Old Westbury: The Feminist Press.

Emslie C and Hunt K (2008) The weaker sex? Exploring lay understandings of gender differences in life expectancy: A qualitative study. Social Science \& Medicine, 67(5): $808-816$

Esplen E (2009) Gender and Care: Overview Report. Brighton: Institute of Development Studies.

Fassin É (2006) Le genre aux États-Unis et en France [Gender in United-States and in France]. Agora débats/jeunesse 41: 12-21.

Fredrickson BL and Roberts TA (1997) Objectification Theory: Toward Understanding Women's Lived Experiences and Mental Health Risks. Psychology of Women Quarterly 21(2): 173-206.

Flick U (1996) Social Representations. In: Harré R, Smith J and van Langenhove L (eds) Rethinking Psychology (2nd ed.). London: Sage, pp. 70-96.

Flick U (2001) Qualitative inquiries into social representations of health. Journal of health psychology 5 (3): 315-324. 
Flick U (2014) An introduction to qualitative research. London: Sage.

Foucault M (1979) Naissance de la biopolitique: Cours au collège de France [The Birth of Biopolotics. Lectures at the Collège de France]. Paris: Seuil.

Grize JB (2015) Logique naturelle et communication [Natural logic and communication]. Paris:

Presses Universitaires de France.

Herzlich C (1973) Health and illness: A social psychological analysis. London: Academic Press.

Hine R (2011) In the Margins: The Impact of Sexualised Images on the Mental Health of Ageing Women. Sex Roles 65(7-8): 632-646.

Hollander JA (2004) The Social Contexts of Focus Groups. Journal of Contemporary Ethnography 33(5): 602-637.

Hughner R and Kleine S (2004) Views of health in the lay sector: a compilation and review of how individuals think about health. Health: An Interdisciplinary Journal for the Social Study of Health Illness and Medicine 8(4): 395-422.

Jodelet D (1991) Madness and Social Representations. Harvest Wheatsheaf: Hemel Hamstead. Joffe H (2007) Identity, self-control, and risk. In: Moloney G and Walker I (eds) Social representations and identity. Content, process and power. New-York: Palgrave Macmillan, pp. 197-214.

Jovchelovitch S and Gervais MC (2001) Social representations of health and illness: The case of the Chinese community in England. Journal of Community \& Applied Social Psychology 9 (4): 247-260.

Kitzinger J (1994) The methodology of focus groups: The importance of interaction between research participants. Sociology of Health and Illness 16(1): 103-121.

Krueger RA and Casey MA (2009) Focus groups: A practical guide for applied research. Thousand Oaks: Sage Publications. 
Lahire B (2001) Héritages sexués : incorporation des habitudes et des croyances [Gendered legacy: embedding of habits and beliefs]. In: Blöss $\mathrm{T}$ (ed) La dialectique des rapports hommes-femmes. Paris: Presses Universitaires de France, pp 9-25.

Lawton J (2003) Lay experiences of health and illness: Past research and future agendas. Sociology of Health and Illness, 25: 23-40.

Lupton D (1995) The imperative of health: public health and the regulated body. London: Sage. Marmot M (2005) Social determinants of health inequalities. Lancet 365(9464): 1099-1104.

Moscovici S (1973) Foreword. In: Herzlich C (ed) Health and illness. London: Academic Press, pp ix-xiv.

Moscovici S (2008) Psychoanalysis: Its image and its public. Cambridge: Polity Press.

Moloney G (2010) Acknowledging Gerard. Articulating social representations and identity through process \& content: the resettlement of refugees in regional Australia. Papers on Social Representations 19(1): 15.1-15.16.

Murray M, Pullman D and Rodgers TH (2004) Social representations of health and illness among 'baby-boomers' in eastern Canada. Journal of Health Psychology 8 (5): 485499.

Pietilä, I and Rytkönrn M (2008) “Health is not a man's domain”: lay accounts of gender difference in life-expectancy in Russia. Sociology of Health and Illness 30(7): 10701085.

World Health Organization (WHO) (2011) Global burden of disease: 2008 update. Geneva: World Health Organization.

\section{Appendix}

Appendix 1. The number of the participants in the focus groups. 


\begin{tabular}{llll}
\hline Group no. & Sex & Abbreviation & Participants \\
\hline 1 & Men & Men1 & 5 \\
2 & Men & Men2 & 4 \\
3 & Men & Men3 & 6 \\
Sub-Total & & & 15 \\
4 & Women & Wom1 & 6 \\
5 & Women & Wom2 & 4 \\
6 & Women & Wom3 & 6 \\
Sub-Total & & & 16 \\
7 & Mixed & Mix1 & 4 \\
8 & Mixed & Mix2 & 6 \\
9 & Mixed & Mix3 & 6 \\
Sub-Total & & & 16 \\
Total & & & 47 \\
\hline
\end{tabular}


Table 2. Summary of social representations related to gender in the health context.

\begin{tabular}{ll}
\hline \multicolumn{1}{c}{ Women } & \multicolumn{1}{c}{ Men } \\
\hline $\begin{array}{l}\text { Understand and take care of mental health } \\
\text { Attitudes and practices are naturally more } \\
\text { preventive and protective (care) }\end{array}$ & $\begin{array}{l}\text { More concerned by physical health } \\
\text { (Apparent) disinterest in health } \\
\text { considerations }\end{array}$ \\
Victims of potential outside aggression & $\begin{array}{l}\text { Confront/seek risk-taking for fun or } \\
\text { challenges }\end{array}$ \\
$\begin{array}{l}\text { Vulnerable } \\
\text { Ease in expressing their feelings and } \\
\text { health issues }\end{array}$ & $\begin{array}{l}\text { Refusal to admit or recognise their } \\
\text { pain/disorder }\end{array}$ \\
$\begin{array}{l}\text { Ease in seeking help } \\
\text { "Excessive" use of healthcare }\end{array}$ & $\begin{array}{l}\text { Autonomous, don't need/seek help } \\
\text { Lesser recourse to care due to a } \\
\text { certain masculinity }\end{array}$ \\
$\begin{array}{l}\text { Self-objectification and health-related self- } \\
\text { monitoring (notably gynaecological) }\end{array}$ & $\begin{array}{l}\text { Mystery regarding men's genital } \\
\text { surveillance }\end{array}$ \\
$\begin{array}{l}\text { Significant amount of health information } \\
\text { that directly concerns women }\end{array}$ & $\begin{array}{l}\text { Limited health information that } \\
\text { directly concerns men: men's health } \\
\text { issues considered as less problematic } \\
\text { or worthy }\end{array}$ \\
$\begin{array}{l}\text { The media and women themselves are } \\
\text { more invested in the body beautiful and } \\
\text { women's health }\end{array}$ & $\begin{array}{l} \\
\text { homan (future) children }\end{array}$ \\
\hline
\end{tabular}

